\title{
A Study on Deformation of Land and Loss of Vegetation Due to Mining at Barapukuria Coal Mine
}

\author{
I. Abedin ${ }^{1 *}$, M. A. N. Abir' ${ }^{1}$, A. Hussain ${ }^{1}$, G. Hasan ${ }^{2}$ \\ ${ }^{1}$ Department of Petroleum and Mining Engineering, Chittagong University of Engineering and \\ Technology, Raozan-4349, Chittagong, Bangladesh \\ ${ }^{2}$ Departmentof Urban Regional Planning, Chittagong University of Engineering and Technology, \\ Raozan-4349, Chittagong, Bangladesh
}

Received 7 March 2019, accepted in final revised form 15 June 2019

\begin{abstract}
Barapukuria coal mine is the biggest coal mine in Bangladesh discovered in 1985. It has lease area around 10.53 square $\mathrm{km}$ with the total reserve of 390 million tons. Though it fulfils the major portion of demand of coal in Bangladesh nevertheless it has severe effect like deformation of topography of that surface area while extracting coal from mine and causes severe impact on vegetation on the coal mine vicinity. This is due to some poor design of extraction process. The intent and purpose of this research is to make an analysis of the influence of topography changes due to mining and impact on vegetation. To assess the effect of mining on vegetation and topography remote sensing technology, GIS and Landsat image were used. Our study confirms the deformation of topography and loss of vegetation due to mining. If this mining process continue it will create adverse effect on environment. The result is expected to be a reference for various parties to perform activities related to the mining of coal in Barapukuria coal mine.
\end{abstract}

Keywords: Barapukuria; Topography; Vegetation; GIS; Simulation.

(c) 2019 JSR Publications. ISSN: 2070-0237 (Print); 2070-0245 (Online). All rights reserved. doi: http://dx.doi.org/10.3329/jsr.v11i3.40513 J. Sci. Res. 11 (3), 293-301 (2019)

\section{Introduction}

The worldwide need for energy resources requires increased production of coal and other fuels. A large amount of this production will eventually come from underground mining in areas where surface mining is impractical or uneconomical. Past coal mining practice left much coal in the ground as pillars that are difficult to recover. Present day emphasis is on improving extraction percentage. Because both the methods of extraction and the numberof mines will increase overall subsidence risk, we must be able to accurately

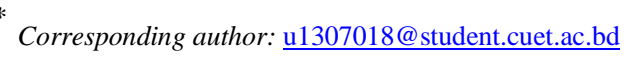


predict the surface and underground impacts of subsidence and, if necessary, to suggest means to lessen these impacts.

The Barapukuria coal field was discovered by the Geological Survey of Bangladesh (GSB) in 1985 in the drill hole GDH-38, which encountered coal seams at a depth of 159 $\mathrm{m}$. The coal reserve found in the Barapukuria is 303 million tons. The coalfield is situated within the Barapukuria village of under Parbatipur Thana, Dinajpur district, at a distance of about $50 \mathrm{~km}$ southeast of Dinajpur town (mentioned in Fig. 1). The Barapukuria coal mine started commercial production of coal by early 2005 by underground mining method (LTCC) only from the central part of the coal field. Annual production target of the mine is 1 million ton per year for 25 years mine life with daily production of 4000-5000 metric ton. In this study, we would like to focus on deformation of land and loss of vegetation due to mining activities in Barapukuria coal field and try to make some suggestion to reduce these type of impacts $[1,2]$.

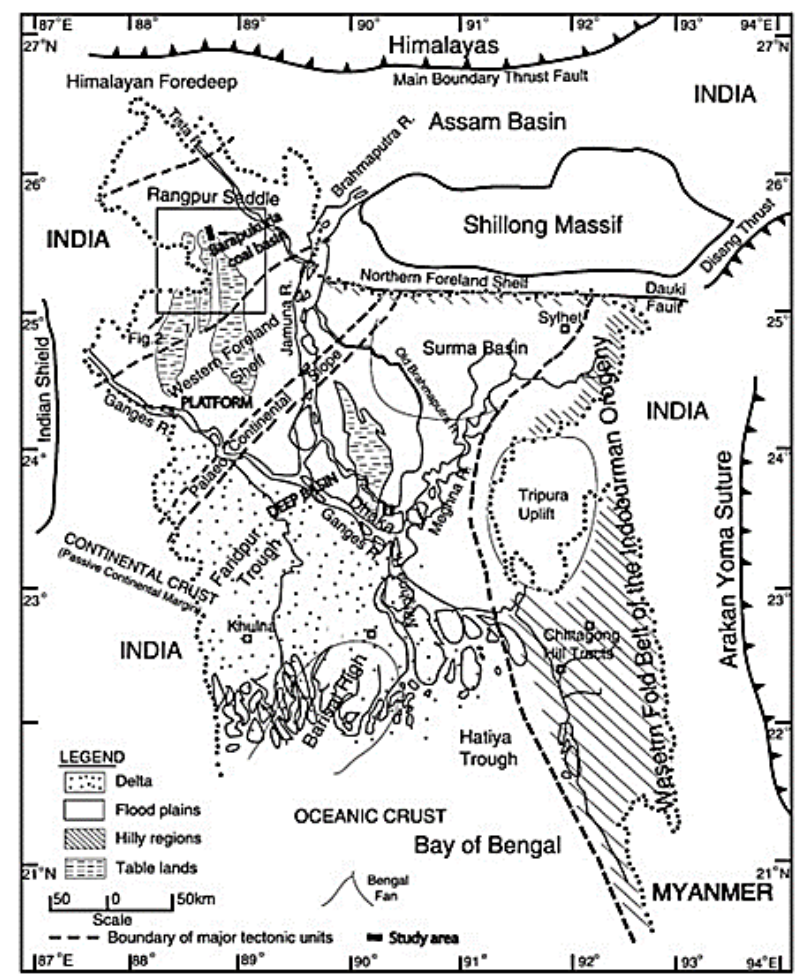

Fig. 1. Study area of Barapukuria coal field [1].

\section{Deformation of Land Due to Mining at Barapukuria Coal Mine}

Deformation of land can be assessed by Topography map. Topography indicates shape and feature of surface land. For large scale area Topography map is helpful to realize surface condition. 
Here the maps were obtained from google earth that is further processed by ARC GIS. The aim from this is to provide evidences of land deformation at the coal mine vicinity over the years of its working periods.

\subsection{Maps of Barapukuria coal mine showing change in terrain level}

Fig. 2 is the map of Barapukuria coal mine at the year of 2000. If the standard mean sea level is $30 \mathrm{~m}$ then the height of the blue portion (which is the land and is comparatively high) will be around $(42.06-30)=12.06 \mathrm{~m}$ and the height of brown portion will be $1.46 \mathrm{~m}$.

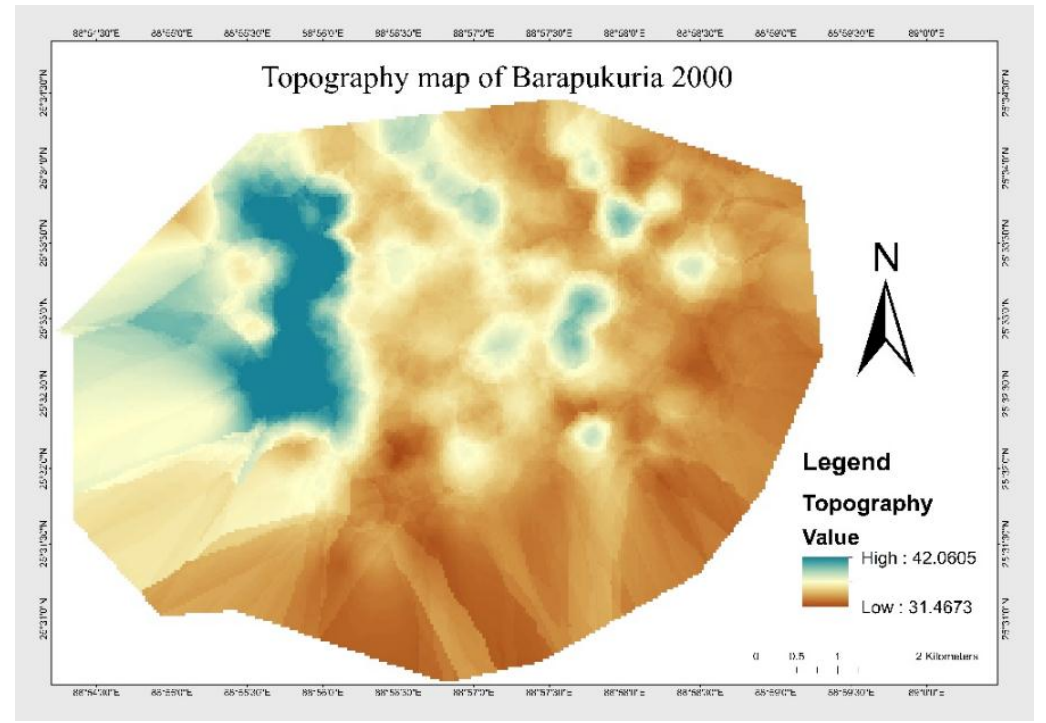

Fig. 2. Topography map of Barapukuria at year 2000(using DEM).

On the other hand, at Fig. 3 the height of the blue or high land is $(41.62-30)=11.62 \mathrm{~m}$ and low land is $(31.03-30)=1.03 \mathrm{~m}$.

By comparing these two maps it clearly shows that the portion which was high at year 2000, was subsided around $(12.06-11.62)=0.44 \mathrm{~m}$ and the amount is $(1.46-1.03)=0.43$ mfor the lower portion, which are clear evidences of land subsidence on the area of study.

In spatial statistics the theoretical semi variogram is a function describing the degree of spatial dependence of a spatial random field or stochastic process. By the use of semi variogram map (Fig. 4), it is also shown the clear evidence of subsidence at different ground control point level. By assessing and evaluating the points of elevation points, it is shown that it deviates from the actual curve it should be. The level of deviation is up to $4 \mathrm{~m}$ in some ground points. 


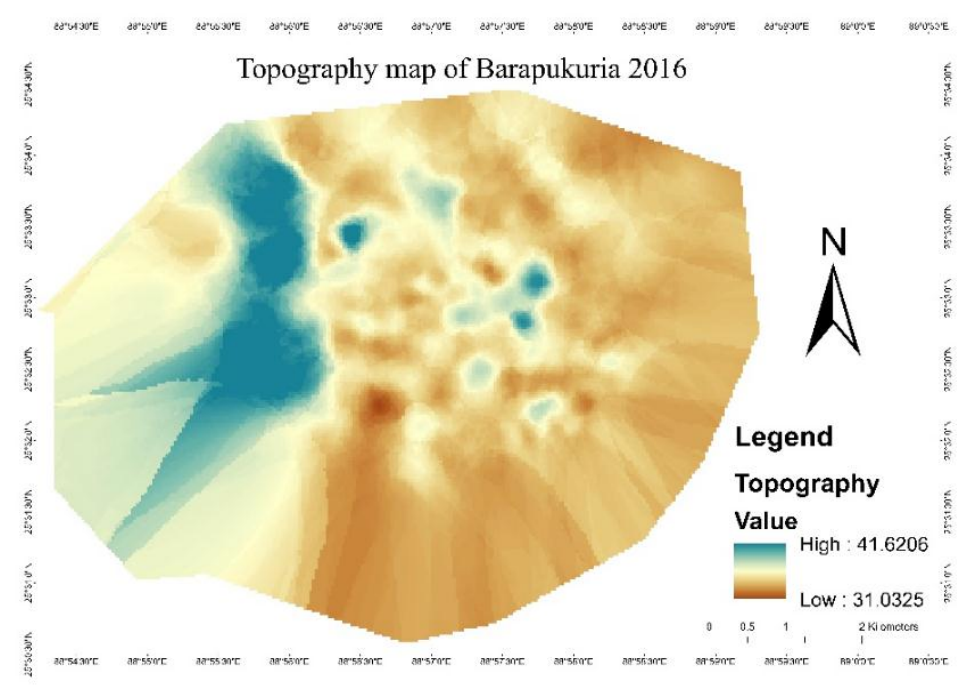

Fig. 3. Topography map of Barapukuria at year 2016 (using DEM).
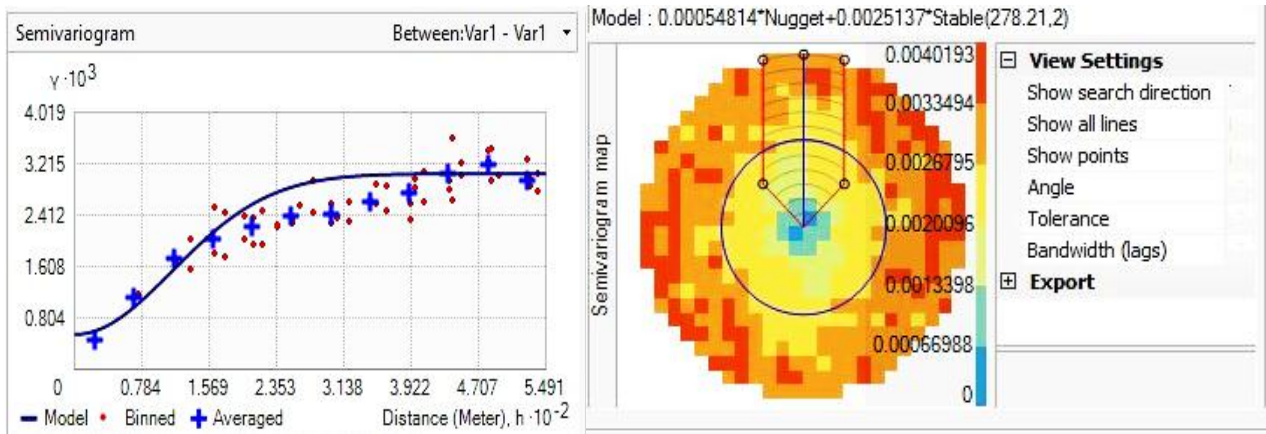

Fig. 4. Semi variogram map (from 2004 to 2016).

\subsection{Measuring the level of subsidence from excel graph}

Plotting elevation from sea level for different ground control point for different time in Microsoft Excel, we get the following graph. 
50.00

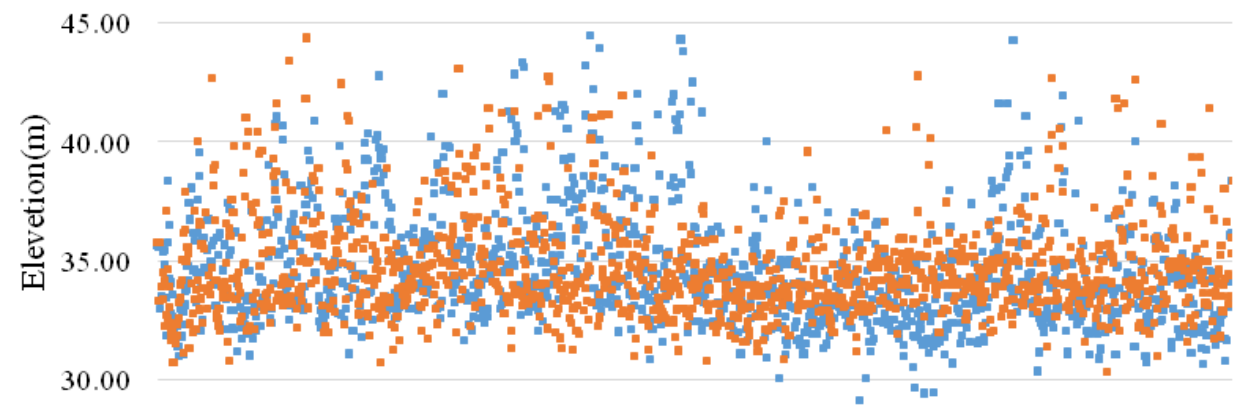

25.00

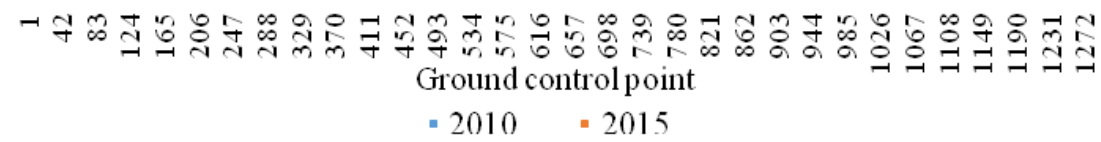

Fig. 5. Elevation variation graph of Barapukuria.

From the above graph (Fig. 5), the blue lines indicate the elevation of year 2010 and brown line indicates the elevation of year 2015. By taking a random ground control point, by taking ground control point 651, we can state that at year 2010 the height of the land was around $44 \mathrm{~m}$ and at the year of 2015 it deforms to around $39 \mathrm{~m}$. That means it clearly shown that there was a deformation of land of that certain ground control point.

\subsection{Images of the subsided area}

Subsidence in Barapukuria is not only matter of theoretical or mathematical calculation, but also a practical phenomenon (Figs. 6 and 7). A noticeable land subsidence occurred at Kalupara village, south-southeast of the Barapukuria mine [3]. Other subsided areas are Moupukur, Jigagari, Sardarpara, Kalupara and Bashpara [4]. Barapukuria Coal Mine Company Ltd (BCMCL) provides enough compensation to the affected people and housing for them in Palashbari, Dhulaudul, Parbatipur, Dinajpur. They acquired total 30 acres of land and constructed 64 barak houses [5]. Subsided lands are now used for fish farming. 

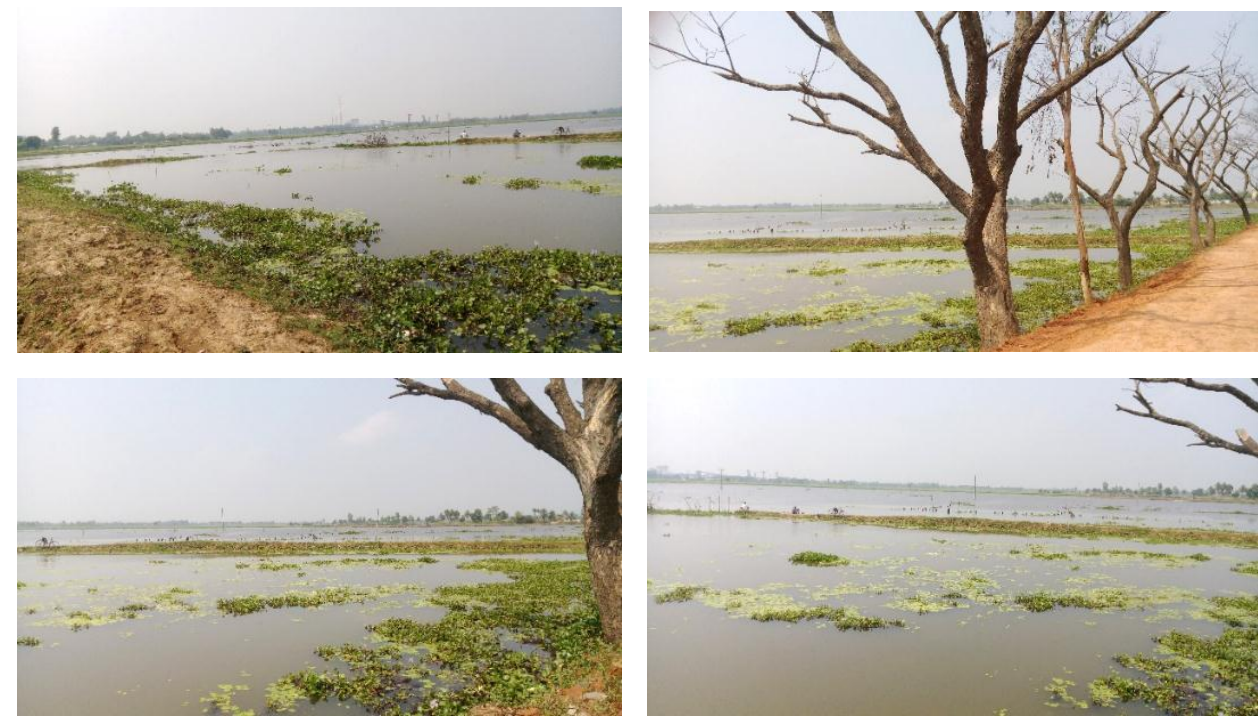

Fig. 6. Images of subsided area adjacent to Barapukuria Coal Mine (captured by author).
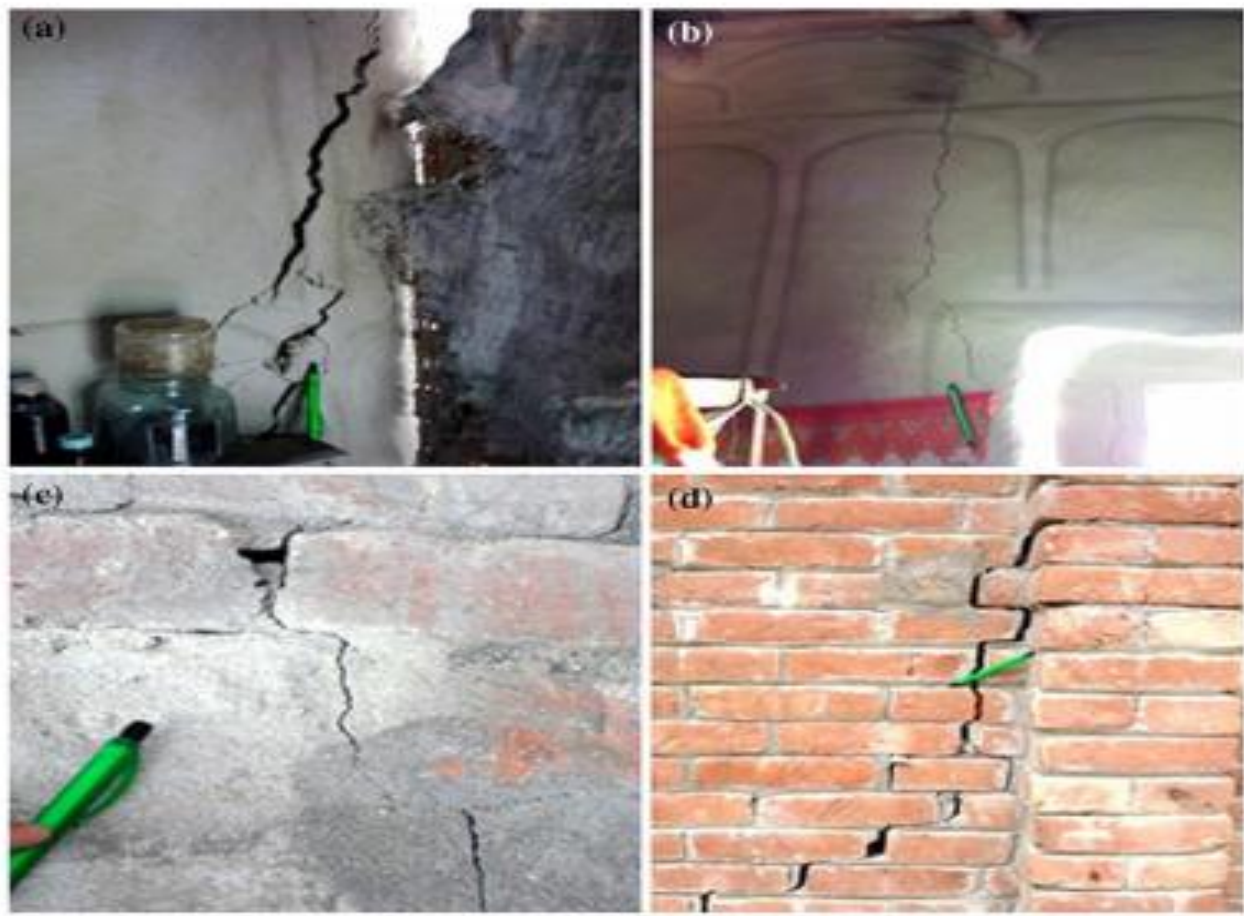

Fig. 7. Subsidence impact on structures. For example, these representative photographs showing the effects of land subsidence on mud wall (a and b) and brick wall (c and d) around the Barapukuria coal mining area [6]. 


\subsection{Loss of vegetation}

Vegetation is an important part of environment. It may be subjected to change during times in areas close to mines. The normalized difference vegetation index (NDVI) is a graphical indicator that can provide realization for vegetation scenario of measurement area. The data can be found by remote sensing measurements [7].

The maps are processed by using normalizes difference vegetation index (NDVI). The data or images of the study area (Barapukuria Coal Mine and its surroundings) were taken landset-8satellite. By analyzing those images that has been simulated to evaluate the density of that specific area, the change of density of vegetation on that specific area of study can be determined. Here, red color indicates the highest vegetated area where green color indicates the lowest.

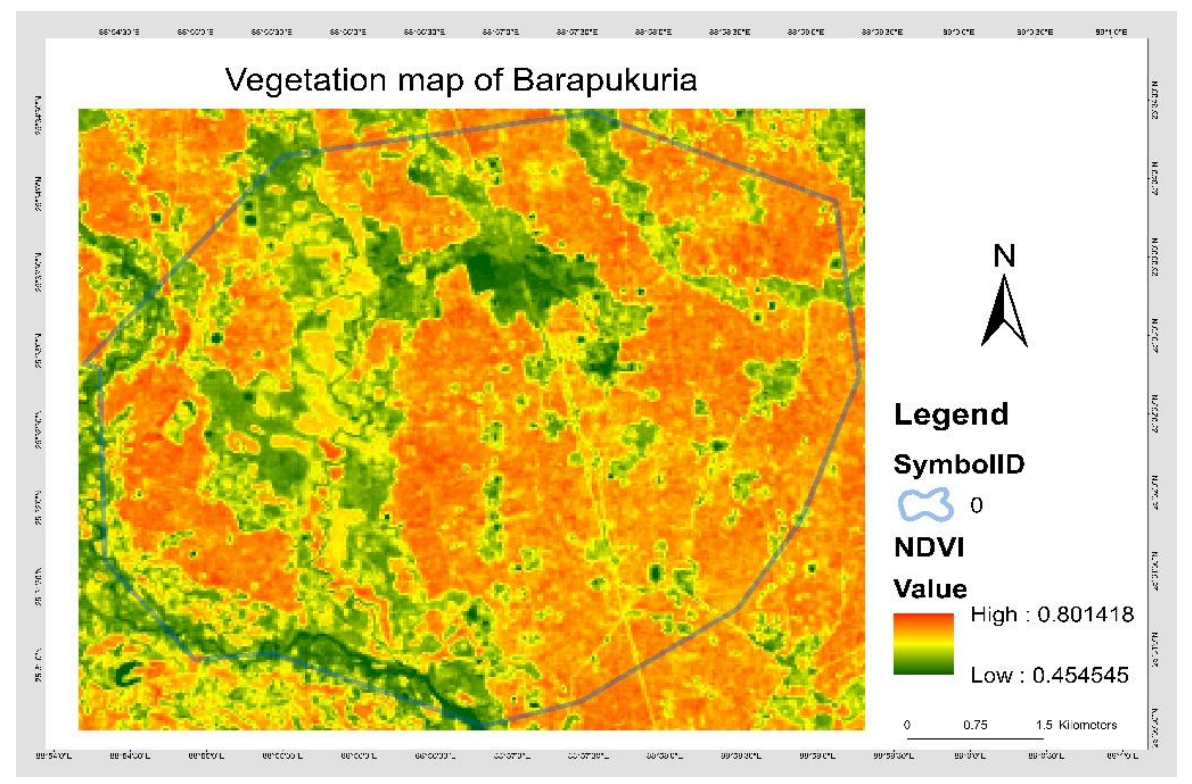

Fig. 8. Vegetation map of Barapukuria at 2010 (using NDVI).

From Fig. 8, which is the vegetation map of Barapukuria Coal Mine at the year of 2010, it is shown that the NDVI value at high land was 0.801418 and at low was 0.454545 .

On the other hand, in Fig. 9, which is the vegetation map at the year of 2018, the NDVI value of high land is 0.694896 and at low was 0.429 , which clearly confirms the loss of vegetation over 18 years of period due to mining activity. 


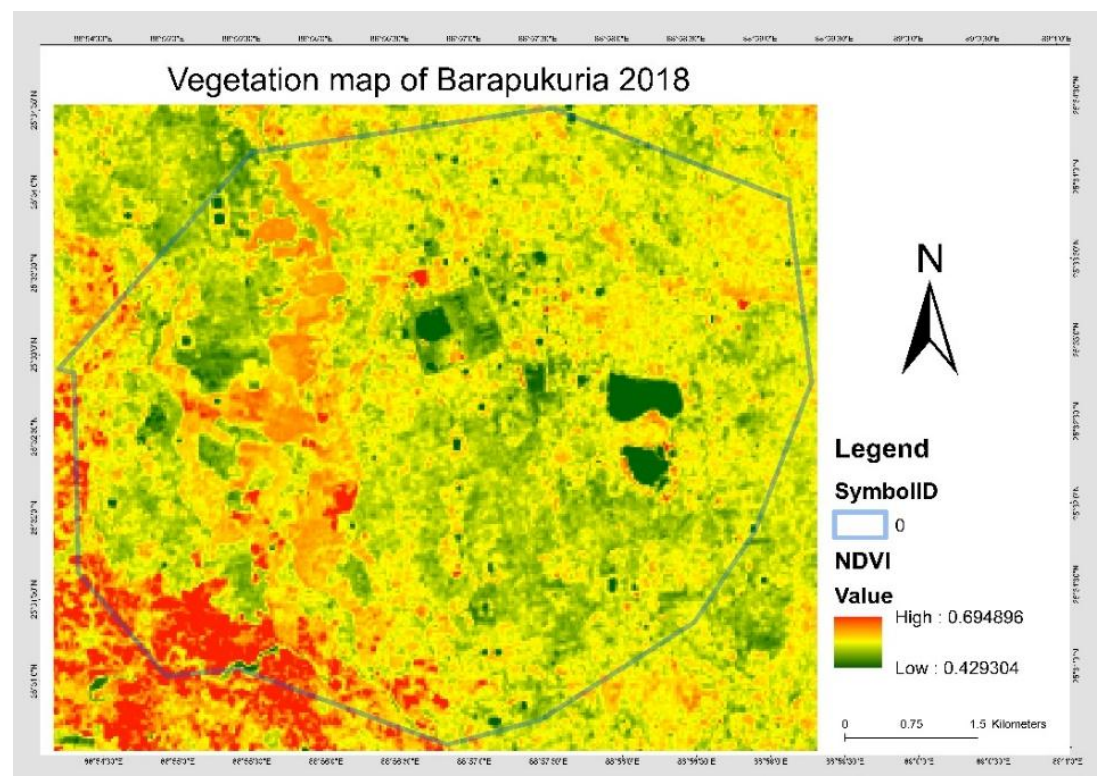

Fig. 9. Vegetation map of Barapukuria at 2018 (using NDVI).

\section{Results and Discussion}

By analyzing and comparing the topographical maps of Barapukuria Coal Mine over the year of 2010 to 2016, it can be clearly said that the ground level is deformed at a significant level, which is around 3to5 feet at the time period of 16 years. It is a clear indication of continuous subsidence at the coal mine area and also its adjacent area. The lands are endangering with the significant chance collapse, which may cause a massive amount of property loss and loss of lives also. On the other hand, it is also creating a massive threat to our environment also by reducing the density of vegetation which is also a great threat to ecological balance also. The main ingredient of environment is the groundwater which emerges during coal extraction and the extent of area where the coal may reach to contaminate the soil [8]. So the groundwater management techniques should be gravely applied at the Barapukuria Coal Mine so that groundwater would not contaminate and become a key agent to vegetation reduction.

\section{Conclusion}

Conventional longwall mining in coal mines gives rise to significant surface subsidence. The deformation of the ground damages local buildings and even modifies the regional landscape. The negative consequences become more serious where intensive coal mining is carried out. The local residents are threatened to be relocated due to underground coal extraction [9]. Therefore, practical and effective approaches to control the surface 
subsidence are in crucial demand for the mining industry. Partial mining and backfill mining is commonly utilized in china to mitigate the ground subsidence. This technique can also be used in our coal fields to mitigate the subsidence and its impacts also [10]. On the other hand, reduction of vegetation must be encountered by proper re-vegetation programs and reducing the spreading of chemical components while transportation or by other means.

\section{References}

1. H. O. Rashid, M. S. Hossain, Z. Urbi, and M. S. Islam, Middle East J. Sci. Res. 21, 268 (2014).

2. M. A. Bakr, Q. M. A. Rahman, M. M. Islam, M. K. Islam, M. N. Uddin, S. A. Resan, M. J. Haider, M. S. Islam, M. W. Ali, M. E. A. Choudhury, K. M. Mannan, and A. N. M. H. Anam, Geology and Coal deposit of Barapukuria Basin, Dinajpur District, Bangladesh, Geological Survey Records of Bangladesh (1996) 8.

3. M. F. Howladar and K. Hasan, A Study on the Development of Subsidence Due to the Extraction of 1203 Slice With Its Associated Factors Around Barapukuria Underground Coal Mining Industrial Area, Dinajpur, Bangladesh (Springer-Verlag, Berlin, Heidelberg, 2014). https://doi.org/10.1007/s12665-014-3419-y

4. Barapukuria The Daily Star, Dhaka, Bangladesh, June 08, 2018.

5. Barapukuria Coal Mine Company Ltd. BCMCL, https://www.bcmcl.org.bd/ (accessed on September 15, 2018).

6. M. F. Howladar, Environmental Impacts of Subsidence Around the Barapukuria Coal Mining Area in Bangladesh (Joint Centre on Global Change and Earth System Science of the University of Maryland and Beijing Normal University and Springer-Verlag Berlin Heidelberg, 2016). https://doi.org/10.1007/s40974-016-0031-x

7. N. Bao, B.Ye, Z. Bai, Sensor Letters, 10, 387 (2012).https://doi.org/10.1166/sl.2012.1895

8. C. Quamruzzaman, M. A. M. Mondol, M. T. Ahmed, S. M. M. Kabir, and Z. Ahmed, Int. J. Emerging Technol. Adv. Eng. 4, 2014.

9. Y. Luo and S. Peng, Using Influence Function Method to Predict Surface Subsidence Caused by High Extraction Room and Pillar Mining - 7th International FIG Symposium on Deformation Measurements (At Banff, Alberta, Canada, 1993)

10. Y. Luo and S. Peng, Long-Term Subsidence associated with long Wall Mining - Its Causes, Development and Magnitude, Mining Eng. 52 (2000). 